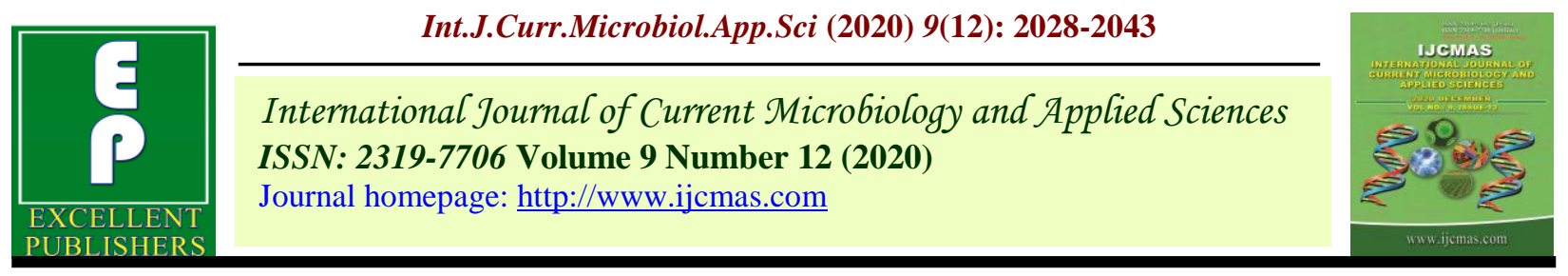

Original Research Article

https://doi.org/10.20546/ijcmas.2020.912.240

\title{
In vitro Evaluation of Endophytic Bacteria for their efficacy against Chickpea Dry Root Rot Causing Pathogen (Rhizoctonia bataticola (Taub.) Butler)
}

\author{
N. Chiranjeevi", M. Reddi Kumar, B. Padmodaya, N.C. Venkateswarlu, \\ P. Sudhakar, R. Sarada Jayalakshmi Devi and M.K. Jyothsna
}

Department of Plant Pathology, S.V Agricultural College, Tirupati, A.P, India

*Corresponding author

\author{
A B S T R A C T
}

\section{Keywords}

Survey, Symptoms, Pathogenicity, Disease incidence and Endophytic bacteria

Article Info

Accepted:

14 November 2020

Available Online:

10 December 2020
A survey was conducted during January, 2017 rabi season in five major chickpea growing districts of Andhra Pradesh viz., Kurnool, Y.S.R Kadapa, Anantapuramu, Prakasam and Guntur to study the symptoms of dry root rot under field conditions and to isolate the pathogen. The major symptoms observed are bronzing, yellowing and browning of the leaves, browning and blackening of roots, shriveled roots and chlorotic leaves etc., A total of 22 isolates of $R$. bataticola were obtained and purified by single hyphal tip method and single sclerotial isolation technique. Pathogenicity of $R$. bataticola isolates was proved by soil inoculation method. Among the isolates tested maximum disease incidence (100 \%) was observed with $\mathrm{CRb} 9$ and it was considered as a most virulent pathogen isolate. A total of 40 antagonistic endophytic bacteria were isolated from healthy roots of different chickpea varieties and the antagonistic efficiency was tested using dual culture technique. Among the isolates CREB 37 showed maximum antifungal efficiency with $74.04 \%$ inhibition against virulent $R$. bataticola isolate CRb 9.

\section{Introduction}

Chickpea (Cicer arietinum L.) is one of the major cultivated crop in the world like Asia, Africa, Europe, Australia, North America and South America countries. Among chickpea growing states of India, Madhya Pradesh, Maharashtra, Rajasthan, Uttar Pradesh, Andhra Pradesh, Karnataka, Chhattisgarh, Bihar and Jharkhand contribute more than 95 per cent to the total production. India contributes to a major share of the world's chickpea area $(70 \%)$ and production $(67 \%)$ and continues to be the largest chickpea producing nation (Dixit et al., 2019).

Among the diseases, dry root rot and wilt causes severe losses in almost all major chickpea growing states of India. Dry root rot causes 20-30 per cent crop losses in major 
chickpea growing states of India (Nene et al., 2012). Among the several soil-borne fungal diseases, dry root rot caused by $R$. bataticola (Taub.) Butler is the most severe disease of chickpea especially where, the crop is mostly grown in Rabi season under rainfed conditions. Predominantly, disease appears around flowering and podding stage. The first symptom is yellowing and sudden drying of the plants. The tap root becomes dark brown quite brittle in dry soil and shows extensive rotting resulting in the loss of lateral roots. The lower portion of the tap root is often left in the soil when plant is uprooted (Nene et al., 2012).

Sharma et al., (2015) reported that dry root rot commonly occured in chickpea during post-flowering stage which include drooping and chlorosis of petioles and leaflets, initially confined to top leaves of the plant. Leaves and stems of affected plants were usually straw coloured and in some cases, the lower leaves and stems were brown.

The tap root turned into black with signs of rotting and devoid of most of the lateral and finer roots. The dead roots were quite brittle and showed shredding of the bark. The tip of the root was easily broken leaving the lower portion of the tap root in the soil when plants were uprooted. Dark minute sclerotial bodies were also seen on the roots exposed and inner side of the bark or when split open at the collar region vertically.

In A.P, major chickpea growing districts includes Kurnool, Y.S.R Kadapa, Anantapuramu, Prakasam and Guntur and the dry root rot occurrence is severe in these areas. This commences to work on this disease to generate basic information on per cent disease incidence, to search for an alternate possible approach other than use of fungicides for the management of the dry root rot.
Besides, increase in pathogen resistance to the fungicides and environmental concerns regarding fungicide usage led to the alternative methods of chickpea dry root rot management such as biological control. Biological control of dry root rot using antagonistic bacteria has been demonstrated earlier. However, consistent and satisfactory control is yet to be obtained for their use on a large scale by farmers.

Manjunatha and Saifulla (2016) isolated a total of 20 isolates of $M$. phaseolina from ten major chickpea growing states of India. Virulence of the isolates was tested on susceptible chickpea cultivars viz., H 09-23, L-550 and BG-212. Out of 20 isolates, only five isolates KAMP-2, KAMP-3, KAMP-4, TNMP-10 and PUMP-14 caused cent per cent dry root rot incidence on all the three cultivars.

Pathogenicity of chickpea dry root rot causing pathogen $R$. bataticola was proved by following two methods of inoculation i.e. seed and soil inoculation techniques (Lakhran et al., 2018).

Plants are ubiquitously colonized by endophytic microorganisms which contribute significantly to plant health through production of plant growth regulators or disease suppression. Endophytes have been reported to possess the potential to produce an array of bio-active metabolites with antifungal properties which enables the host plants to meet possible challenges generated by phytopathogenic fungi. Many endophytic bacteria have been reported to exhibit excellent natural product biosynthetic potential and hence much interest has been generated in recent years to develop bacterial based commercial formulations (Jasim et al., 2016).

Endophytic competence of antagonistic bacteria in roots of many crops is a vital area 
of research that requires elaborate exploration for successful management of plant diseases by biocontrol agents. Hence, the present investigation was undertaken to exploit endophytic microbes and their antibiotic compounds antagonistic to $R$. bataticola, and to study the feasibility of using them in chickpea ecosystem against dry root rot management.

Endophytes can be used as biocontrol agents, due to their capacity to inhibit the growth of pathogens through the production of antifungal or antibacterial compounds, such as siderophores, antibiotics and hydrogen cyanide (HCN) (Santoyo et al., 2016).

Among the most commonly isolated bacterial genera are Bacillus, Burkholderia, Microbacterium, Micrococcus, Pantoea, Pseudomonas and Stenotrophomonas, where Bacillus and Pseudomonas are the predominant genera (Chaturvedi et al., 2016).

Zhao et al., (2018) tested the inhibitory activity of 276 endophytic bacteria against pathogenic fungus Phytophthora sojae in vitro. Only six strains showed more than $63 \%$ inhibitory activity and these isolates were used for further studies.

Ferchichi et al., (2019) assessed antifungal activity of 22 endophytic bacterial isolates against $M$. phaseolina and Alternaria alternate phytopathogens by dual culture technique. Four strains affiliated to Pseudomonas genus (Pseudomonas brenneri LJ215, Pseudomonas frederiksbergensis LB113, Pseudomonas helleri LJ127 and Pseudomonas rhodesiae LJ22) showed an anti-fungal activity against these two phytopathogens simultaneously.

Bhavani et al., (2015) tested 63 endophytic bacterial isolates for their antagonistic properties against $R$. bataticola causing dry root rot of chickpea. Out of them five isolates showed significant inhibition. The isolate B5 was shown the most significant inhibition with $81 \%$, K1 with $77 \%$, K2 with $75 \%$, C2 and $\mathrm{A} 8$ with $74 \%$.

\section{Materials and Methods}

Roving survey was conducted during Rabi 2017-18 in major chickpea growing areas of Andhra Pradesh such as Kurnool, Y.S.R Kadapa, Anantapuramu, Prakasam and Guntur districts. In each district, 2 mandals were selected, in each mandals two villages were taken and in each village, 3 fields were surveyed to study the incidence of dry root disease.

Four $1 \mathrm{~m}^{2}$ quadrants were randomly selected in each field and infected plants were counted in each quadrant. Based on infected and total number of plants, per cent disease incidence was calculated. Chickpea plants showing the typical dry root rot symptoms and healthy plants were collected from surveyed areas, packed in labeled paper bags separately and brought to the laboratory for isolation of the pathogen and root endophytic bacteria.

\section{Isolation of pathogen}

Different isolates of the pathogen was isolated from dry root rot infected chickpea plants by using tissue segment method (Rangaswamy and Mahadevan, 1999). Small pieces of tissue (1-10 $\mathrm{mm}$ dia) from the infected collar region along with some healthy tissue were cut with sterile scalpel. Then the pieces were surface sterilized with $1 \%$ Sodium hypochlorite for 2 min, followed by washing with sterile distilled water thrice to remove traces of Sodium hypochlorite on the bits of tissue. The sterilized pieces were transferred to preplated PDA medium. Plates were incubated at $28 \pm$ $2^{\circ} \mathrm{C}$ and observed periodically for growth of the fungus. The pathogen cultures were purified by single hyphal tip method and single sclerotial isolation method and 
maintained on PDA by periodical transfer throughout the present investigation.

\section{Identification of Pathogen}

The pathogen isolates were identified based on its mycelial and sclerotial characters as described by Commonwealth Mycological Institute (CMI) (1970) and Barnett and Barry (1972).

\section{Pathogenicity test}

Pathogenicity test was proved by using soil infestation method. The pathogen isolates were mass multiplied on sterilized sorghum grains in $250 \mathrm{ml}$ conical flasks. The flasks containing sorghum seeds were autoclaved at $15 \mathrm{psi}$ for $20 \mathrm{~min}$. Then the flasks were inoculated with 4 discs of $5.0 \mathrm{~mm}$ diameter mycelial growth of 3 days old culture of $R$. bataticola isolates grown on PDA plates. The flasks were incubated at $28 \pm 2^{\circ} \mathrm{C}$ for 7 days. Then the inoculums was mixed with sterilized soil @ $100 \mathrm{~g} \mathrm{~kg}-1$ soil and filled in the pots (22.5 cm diameter). The seeds of chickpea cultivar L550 (Dry root rot susceptible variety) were sown simultaneously with pathogen inoculation@10 seeds per pot and an uninoculated control was maintained. Each treatment was replicated thrice. The plants were observed for root rot symptoms and per cent disease incidence was calculated by using formula as mentioned below.

PDI $=$ Number of diseased plants/ Total number of seeds planted

The pathogen isolates which showed maximum disease incidence was considered as a virulent and used for further studies.

\section{Isolation of Native Antagonistic Root Endophytic Bacteria}

For isolation of root endophytic bacteria, $5 \mathrm{~g}$ of healthy root was surface sterilized with 1
$\%$ Sodium hypochlorite for $10 \mathrm{~min}$ and $70 \%$ ethanol for $5 \mathrm{~min}$, followed by five washings was done with sterile distilled water to remove traces of Sodium hypochlorite on the bits of tissue and homogenized in $20 \mathrm{ml}$ of sterilized phosphate buffer (0.2 M Na2HPO4 $+0.2 \mathrm{M} \mathrm{NaH} 2 \mathrm{PO} 4, \mathrm{pH} 7.0$ ) using mortar and pestle. Appropriate dilution (10-6) of this suspension was plated on NA for the isolation of bacteria. The plates were incubated for 24 hrs at $28 \pm 2{ }^{\circ} \mathrm{C}$ (Aravind et al., 2009). One day old colonies of bacteria were picked up and purified by streak plate method.

\section{In-vitro evaluation of endophytic bacteria for their efficacy against the test pathogen R. bataticola}

Dual culture technique was used to evaluate the potential antagonistic isolate of endophytic bacteria. Mycelial disc measuring $6 \mathrm{~mm}$ diameter from 3 days old culture of pathogen, $R$. bataticola (virulent pathogen isolate) was inoculated at the center of $9.0 \mathrm{~cm}$ dia. Petriplate containing equal amount of KB and PDA medium. Test endophytic bacterial cultures were streaked individually on both the sides of the $R$. bataticola at $2.5 \mathrm{~cm}$ distance leaving $2.0 \mathrm{~cm}$ from periphery, Plates inoculated with $R$. bataticola alone were used as checks. Inoculated plates were incubated at $28 \pm 2 \mathrm{oC}$ and observations were recorded as zone of inhibition upto 4 days (when $R$. bataticola completely occupied the plate in monoculture check) (Lahlali et al., 2007 and Reddy et al., 2010). Per cent inhibition of mycelial growth of test pathogen over control was calculated by using the following formula.

Per cent inhibition $(\mathrm{PI})=\mathrm{C}-\mathrm{T} / \mathrm{C} \times 100$

Where,

$\mathrm{C}=$ Growth of test pathogen in the absence of antagonist $(\mathrm{cm})$,

$\mathrm{T}=$ Growth of test pathogen in the presence of antagonist $(\mathrm{cm})$. 


\section{Results and Discussion}

\section{Symptomatology and Collection of Pathogenic Isolates of $R$. bataticola}

In Andhra Pradesh, a roving survey was conducted during January, 2017 in three Rayalaseema districts viz., Kurnool, Y.S.R Kadapa and Anantapuramu and in two Coastal districts viz., Prakasam and Guntur to assess the status of dry root rot incidence under field conditions and collected diseased and healthy plants for the isolation of the pathogen and antagonistic root endophytic bacteria respectively. During survey, due to variation in sowing dates in different districts, different crop growth stages i.e. from seedling (20 days old) to podding stage were observed. The crop was sown in Kurnool, Anantapuramu and Y.S.R Kadapa during first fortnight of October while in Prakasam and Guntur sown in the second fortnight of October. In Prakasam and Guntur, seedlings infected with dry root rot appeared stunted without any lateral roots when uprooted and the tap root was black in colour. In Kurnool, Anantapuramu and Y.S.R Kadapa crop was in the vegetative to podding stage. Symptoms on affected plants were observed as bronzing of the leaves on one or more of the lower branches, leaves became yellow to brown in plants showing advanced disease symptoms. In such plants, the affected branches and leaf stalks were stiff, turned upwards and the leaflets stand more or less vertically and were shed prematurely. The terminal part of the tap root and lateral roots became brown to black and shriveled (Plate 1). The tap root without any lateral roots was also observed. The disease was scattered in the field as dried plants (Plate 1). It was also observed that, the susceptibility of plant to this disease increased with age. Sometimes the apical leaves on the affected plants appeared chlorotic, when the rest of the plant was dry. The pods on affected plants were poorly developed and the number of pods per plant was less. Plants showing different symptoms at different stages of the crop growth were collected along with healthy plants and kept in separate paper bags for conducting further studies. Similar symptoms were observed by Dastur (1935) as yellowing of leaves which later converted to brown in colour. The affected branches and leaflets were stiff and turned upwards, stand vertically and shed prematurely. Nene et al., (1991) observed infection in seedling stage. When the plants were uprooted, the lower portion of tap root remained inside the soil and devoid of most of lateral roots. Dry root rot disease of chickpea usually occurs during reproductive phase of the crop, around flowering and podding time as scattered dried plants (Sharma et al., 2015). The seedling stage may be affected by the disease but the old plants are more susceptible towards infection (Sharma and Pande, 2013)

\section{Isolation and identification of the fungus}

Different isolates of $R$. bataticola were isolated from the samples collected from major chickpea growing areas of Andhra Pradesh. The isolates were purified by single sclerotial isolation technique and were identified as $R$. bataticola based on morphological and cultural characters using the descriptions given by C.M.I (1970) and Barnett and Barry (1972). The isolates were designated serially from $\mathrm{CRb} 1$ to $\mathrm{CRb} 22$ (Plate 2). The mycelium was initially light brown in colour which was later converted to dark brown to black in colour. Production of aerial mycelium was also observed in some isolates. The vegetative mycelium was characterized by the formation of barrel shaped cells and the formation of septum near the origin of branch of the mycelium. Branching occurred mostly at right angle to parent hyphae, but branching at acute angles was also observed. Sclerotial size varied from $44.27 \mu \mathrm{m}(\mathrm{CRb} 16)$ to $119.32 \mu \mathrm{m}(\mathrm{CRb} 6)$. 
The shape of sclerotia varied from round, ovoid to irregular. The sclerotia were grey and light to jet black in colour. The above observations were in accordance with the descriptions given by Short and Wyllie (1978) as branching occurs at right angle to parent hyphae but branching at acute angles was also common. Microsclerotia were formed from the aggregation of hyphae with 50 to 200 individual cells. The microsclerotia of $R$. bataticola were black in colour and size varied from 50 - $150 \mu \mathrm{m}$ with respect to host and media used.

Devi and Singh (1998) observed bigger sclerotia in isolate MP - $2(400 \times 280 \mu \mathrm{m})$ while working on $R$. bataicola isolates in mungbean. They also observed typical right angled branching of mycelium in one of the isolates and acute to right angle branching in certain isolates.

\section{Proving the pathogenicity and screening of different isolates of $\boldsymbol{R}$. bataticola}

Pathogenicity of the 22 isolates of $R$. bataticola obtained from different growing areas of chickpea was tested by soil inoculation method. The data pertaining to germination per cent and disease incidence was presented in the Table 1 .

About 10 seeds of chickpea were sown in each pot with a diameter of $22.5 \mathrm{~cm}$ (sterilized) inoculated with pathogen @ $100 \mathrm{~g}$ $\mathrm{kg}^{-1}$ soil. Pre-emergence rot of seedlings was observed and the survived plants showing stunted growth followed by wilting and drying of leaves and stems (Plate 4.4).

When the infected plants were pulled out, blackening of tap root and devoid of lateral as well as finer roots was observed. On reisolation, the characters of the pathogen showed similarity with the original pathogen isolated from the field, thus fulfilling Koch's postulates. Observations were recorded on per cent germination and disease incidence $(\%)$.

The data indicated that among the isolates tested maximum germination $(100 \%)$ was observed in $\mathrm{CRb} 14, \mathrm{CRb} 20$ and un inoculated control and at par with $\mathrm{CRb} 3$ (96.67\%), CRb 13 (96.67\%), CRb 15 (96.67 $\%), \mathrm{CRb} 4$ (93.33\%), CRb 16 (93.33\%), CRb 9 (90.00\%), CRb 18 (90.00\%) and CRb $21(90.00 \%)$ and significantly differed with all other remaining isolates. Least germination percentage was recorded with CRb 7 (76.67\%) which was at par with CRb 5 (8.00\%), CRb 6 (80.00\%), CRb 19 (80.00 $\%)$ and $\mathrm{CRb} 22(80.00 \%)$ and significantly differed with all other remaining isolates.

Among the 22 isolates, maximum disease incidence was observed in CRb 9 (100 \%) followed by $\mathrm{CRb} 3$ (86.67 \%), CRb 1, CRb 10, CRb 13, CRb 14, CRb 20 (83.33 \%) CRb 2, CRb 4, CRb 11, CRb 12 (80.00\%), CRb 8, CRb 15 (76.67 \%), CRb 16, CRb 17, CRb 21 (73.33\%), CRb 18, CRb 19, CRb 22 (70.00 $\%), \mathrm{CRb} 5, \mathrm{CRb} 7$ (63.33\%) and $\mathrm{CRb} 6$ $(60.00 \%)$ and least incidence was observed with control $(0.00 \%)$ which was significantly differed with all the isolates.

Based on the above results, $\mathrm{CRb} 9$ isolate showed higher disease incidence (100\%) compared with all the remaining isolates and hence, it was considered as a most virulent isolate and used for further studies.

Several workers have found soil inoculation method as most suitable in establishing the disease caused by $R$ bataticola and proved the pathogenicity (Vishwadar and Sarbhoy (1993) in soybean, Devi and Singh (1998) in greengram, Veena et al., (2014), Reddy et al., (2010) and Katariya et al., (2007) in chickpea and Kanchan and Biswas (2009) in pigeonpea. 
Isolation of endophytic bacterial isolates from chickpea roots

A total of 40 antagonistic endophytic bacteria were isolated from healthy roots of disease affected fields of different chickpea varieties which are popularly cultivated in surveyed areas (Kurnool, Y.S.R Kadapa, Prakasam, Anantapuramu and Guntur). Isolation of endophytic bacteria was carried out as per the procedure given in section 2.4. The bacteria were isolated on Nutrient Agar (NA) medium and were purified by streak plate method and maintained on Nutrient agar medium. The endophytic bacterial isolates obtained from internal tissues of healthy roots were designated as CREB-1 to CREB-40 (Table 2 and Plate 3). The results from the Table 2 revealed that a total of 11 endophytic bacterial isolates were isolated from the root samples collected from six villages of three mandals in Kurnool district. Among the 11 isolates, two (CREB 1 and CREB 2) from L. Peta of Kurnool mandal, one (CREB 3) from Peddapadu of Kurnool mandal, two (CREB 4 and CREB 5) from Kodumur of Kodumur mandal, three (CREB 6, CREB 7 and CREB 8) from Venkatagiri of Kodumur mandal, one (CREB 9) from Ayyalur of Nandyal mandal and (CREB 10 and CREB 11) from Chapirevula of Nandyal mandal.

Similarly, a total of six endophytes were isolated from the samples collected from four villages of two mandals in Y.S.R Kadapa district. Among the six, two (CREB 12 and CREB 13) from Dharmapuram of Jammalamadugu mandal, one from (CREB14) from Devagudi of Jammalamadugu mandal, two (CREB 15 and CREB 16) from Dhorasanipalli of Prodduture mandal and one (CREB 17) from Ramapuram of Prodduture mandal.

However, a total of eight endophytic bacterial isolates were obtained from root samples collected from four mandals in Prakasam district. Among the eight bacterial endophytes three (CREB 18, CREB19 and CREB 20) from Cheruvukommapalem of Ongole mandal, One (CREB 21) from Chejerla of Ongole mandal, two (CREB 22 and CREB 23) from Kandukuru of Tanguturu mandal and another two (CREB 24 and CREB 25) from Valluru of Tanguturu mandal.

From Anantapuramu district, a total of seven bacterial endophytes were obtained from four villages across two mandals. Among the seven isolates, one (CREB 26) from Peddadoddi of Gooty mandal, three (CREB 27, CREB 28 and CREB 29) from Basinapalle of Gooty mandal, two (CREB 30 and CREB 31) from Ayyavaripalli of Guntakal mandal and one (CREB 32) from Nakkanadoddi of Guntakal mandal.

A total of eight root endophytic bacterial isolates were isolated from four villages spread across two mandals in Guntur district. Among the eight isolates, two (CREB 33 and CREB 34) from Brahmanapalli of Vinikonda mandal, three (CREB 35, CREB 36 and CREB 37) from Dondapadu of Vinikonda mandal, one (CREB 38) from Gogulapadu of Rompicherla mandal and two (CREB 39 and CREB 40) from Daseripalem.

Saini et al., (2013) isolated the endophytic bacteria from roots (12 isolates) and nodules (76 isolates) of chickpea legume grown under CCS Haryana Agricultural University farm. Similarly, Bhavani et al., (2015) obtained a total of 63 isolates of endophytic bacteria from healthy roots of chickpea which were collected from fields of Balapanur in Kurnool and Shivaji Nagar in Y.S.R Kadapa districts of A.P, India. Veena and Reddy (2016) isolated a total of 20 endophytic bacteria from apparently healthy chickpea roots collected from major chickpea growing areas of Andhra Pradesh. 
In vitro evaluation of endophytic bacteria for their efficacy against $R$. bataticola

The antagonistic effect of endophytic bacterial isolates was assessed based on their ability to inhibit the pathogen growth in dual culture. The effect of these antagonists on the mycelial growth of the pathogen was calculated and expressed as per cent inhibition. The results were presented in Table 3 and Plate 4.

Dual culture was done by inoculating the virulent pathogen isolate $(\mathrm{CRb} 9)$ at the centre of sterile PDA Petriplate of $9 \mathrm{~cm}$ dia. and streaking endophytic bacterial isolate $2.5 \mathrm{~cm}$ away on both the sides of $R$. bataticola and $2.0 \mathrm{~cm}$ inside the periphery.

Table.1 Testing the pathogenicity of different isolates of $R$. bataticola

\begin{tabular}{|c|c|c|c|}
\hline S.No & Isolate code & Germination (\%) & Disease incidence (\%) \\
\hline 1. & $\mathrm{CRb} 1$ & $86.67^{\text {bcde }}(68.83)$ & $83.33^{\mathrm{bc}}(66.12)$ \\
\hline 2. & $\mathrm{CRb} 2$ & $83.33^{\text {cdef }}(66.12)$ & $80.00^{\text {bcd }}(63.90)$ \\
\hline 3. & $\mathrm{CRb} 3$ & $96.67^{\mathrm{ab}}(83.85)$ & $86.67^{\mathrm{b}}(77.69)$ \\
\hline 4. & $\mathrm{CRb} 4$ & $93.33^{\mathrm{abc}}(77.69)$ & $80.00^{\text {bcd }}(63.90)$ \\
\hline 5. & $\mathrm{CRb} 5$ & $80.00^{\operatorname{detg}}(63.90)$ & $63.33^{\operatorname{tgh}}(52.75)$ \\
\hline 6. & $\mathrm{CRb} 6$ & $80.00^{\operatorname{defg}}(63.41)$ & $60.00^{\mathrm{gh}}(50.83)$ \\
\hline 7. & $\mathrm{CRb} 7$ & $76.67^{\operatorname{defg}}(61.20)$ & $63.33^{\text {ggh }}(52.75)$ \\
\hline 8. & $\mathrm{CRb} 8$ & $83.33^{\text {cdef }}(66.12)$ & $76.67^{\text {bcde }}(61.20)$ \\
\hline 9. & $\mathrm{CRb} 9$ & $90.00^{\text {abcd }}(74.98)$ & $100.00^{\mathrm{a}}(90.00)$ \\
\hline 10. & $\mathrm{CRb} 10$ & $86.67^{\text {bcde }}(72.27)$ & $83.33^{\mathrm{bc}}(66.12)$ \\
\hline 11. & $\mathrm{CRb} 11$ & $83.33^{\text {cdef }}(70.06)$ & $80.00^{\text {bcd }}(63.90)$ \\
\hline 12. & CRb 12 & $86.67^{\text {bcde }}(68.83)$ & $80.00^{\text {bcd }}(63.41)$ \\
\hline 13. & CRb 13 & $96.67^{\mathrm{ab}}(83.85)$ & $83.33^{\mathrm{bc}}(66.12)$ \\
\hline 14. & CRb 14 & $100.00^{\mathrm{a}}(90.00)$ & $83.33^{\mathrm{bc}}(66.12)$ \\
\hline 15. & $\mathrm{CRb} 15$ & $96.67^{\mathrm{ab}}(83.85)$ & $76.67^{\text {bcde }}(61.20)$ \\
\hline 16. & $\mathrm{CRb} 16$ & $93.33^{\mathrm{abc}}(77.69)$ & $73.33^{\text {cdet }}(58.98)$ \\
\hline 17. & $\mathrm{CRb} 17$ & $86.67^{\text {bcde }}(72.27)$ & $73.33^{\text {cdef }}(58.98)$ \\
\hline 18. & $\mathrm{CRb} 18$ & $90.00^{\mathrm{abcd}}(74.98)$ & $70.00^{\operatorname{detg}}(56.77)$ \\
\hline 19. & $\mathrm{CRb} 19$ & $80.00^{\operatorname{defg}}(63.90)$ & $70.00^{\operatorname{defg}}(56.98)$ \\
\hline 20. & $\mathrm{CRb} 20$ & $100.00^{\mathrm{a}}(90.00)$ & $83.33^{\mathrm{bc}}(66.12)$ \\
\hline 21. & $\mathrm{CRb} 21$ & $90.00^{\text {abcd }}(71.54)$ & $73.33^{\text {cdef }}(58.98)$ \\
\hline 22. & $\mathrm{CRb} 22$ & $80.00^{\operatorname{defg}}(63.90)$ & $70.00^{\operatorname{defg}}(56.98)$ \\
\hline 23 & Control & $100.00^{\mathrm{a}}(90.00)$ & $0.00^{\mathrm{i}}(0.00)$ \\
\hline \multicolumn{2}{|c|}{ C.D $(P=0.05 \%)$} & $12.55(15.33)$ & $11.05(8.43)$ \\
\hline \multicolumn{2}{|c|}{$\operatorname{SEm}( \pm)$} & $4.40(5.37)$ & $3.87(2.95)$ \\
\hline \multicolumn{2}{|r|}{ SE (d) } & $6.22(7.59)$ & $5.47(4.17)$ \\
\hline \multicolumn{2}{|r|}{ C.V } & $8.58(12.58)$ & $9.07(8.52)$ \\
\hline
\end{tabular}

Note: Values in the parenthesis are angular transformed values. The figures with similar alphabet do not differ significantly. 
Table.2 List of endophytic bacterial isolates collected from major chickpea growing areas of A.P

\begin{tabular}{|c|c|c|c|c|}
\hline S.No & District & Mandals & Villages & Isolate code \\
\hline \multirow{6}{*}{1.} & \multirow{6}{*}{ Kurnool } & \multirow[b]{2}{*}{$\begin{array}{r}\text { Kurnool } \\
\text { (Rural) }\end{array}$} & L. Peta & CREB 1, CREB 2 \\
\hline & & & Peddapadu & CREB 3, \\
\hline & & \multirow[b]{2}{*}{ Kodumooru } & Kodumooru & CREB 4, CREB 5 \\
\hline & & & Venkatagiri & $\begin{array}{c}\text { CREB 6, CREB 7, } \\
\text { CREB } 8\end{array}$ \\
\hline & & \multirow[t]{2}{*}{ Nandyal } & Ayyalur & CREB 9 \\
\hline & & & Chapirevula & CREB 10, CREB 11 \\
\hline \multirow{4}{*}{2.} & \multirow{4}{*}{ Y.S.R Kadapa } & \multirow[t]{2}{*}{ Jammalamadugu } & Dharmapuram & CREB 12 , CREB 13 , \\
\hline & & & Devagudi & CREB 14 \\
\hline & & \multirow[t]{2}{*}{ Prodduturu } & Dhorasanipalli & CREB 15, CREB 16 \\
\hline & & & Ramapuram & CREB 17 \\
\hline \multirow[t]{4}{*}{3.} & \multirow[t]{4}{*}{ Prakasam } & \multirow[t]{2}{*}{ Ongole } & Cheruvukommapalem & $\begin{array}{c}\text { CREB } 18, \text { CREB } 19, \\
\text { CREB } 20\end{array}$ \\
\hline & & & Chejerla & CREB 21 \\
\hline & & \multirow[t]{2}{*}{ Tangutoor } & Kandukuru & CREB 22, CREB 23 \\
\hline & & & Vallooru & CREB 24, CREB 25 \\
\hline \multirow[t]{4}{*}{4.} & \multirow[t]{4}{*}{ Anantapuramu } & \multirow[t]{2}{*}{ Gooty } & Peddadoddi & CREB 26 \\
\hline & & & Basinapalle & $\begin{array}{c}\text {, CREB 27, CREB } \\
\text { 28, CREB } 29\end{array}$ \\
\hline & & \multirow[t]{2}{*}{ Guntakal } & Ayyavaripalli & CREB 30, CREB 31 \\
\hline & & & Nakkanadoddi & CREB 32 \\
\hline \multirow{4}{*}{5.} & \multirow[t]{4}{*}{ Guntur } & \multirow[t]{2}{*}{ Vinikonda } & Brahmanapalli & CREB 33, CREB 34 \\
\hline & & & Dondapadu & $\begin{array}{c}\text { CREB 35, CREB 36, } \\
\text { CREB } 37\end{array}$ \\
\hline & & \multirow[t]{2}{*}{ Rompicherla } & Gogulapadu & CREB 38 \\
\hline & & & Daseripalem & CREB 39, CREB 40 \\
\hline
\end{tabular}

Table.3 Effect of endophytic bacteria on the radial growth (dia.) of $R$. bataticola in vitro using dual culture technique

\begin{tabular}{|c|c|c|c|}
\hline S.No & Isolate code & Mycelial radial growth (cm) & \% Inhibition \\
\hline $\mathbf{1 .}$ & CREB 1 & $1.87^{\mathrm{jklm}}$ & $58.52^{\mathrm{def}}(49.89)$ \\
\hline $\mathbf{2 .}$ & CREB 2 & $4.50^{\mathrm{a}}$ & $0.00^{\mathrm{q}}(0.00)$ \\
\hline $\mathbf{3 .}$ & CREB 3 & $4.50^{\mathrm{a}}$ & $0.00^{\mathrm{q}}(0.00)$ \\
\hline $\mathbf{4 .}$ & CREB 4 & $4.50^{\mathrm{a}}$ & $0.00^{\mathrm{q}}(0.00)$ \\
\hline $\mathbf{5 .}$ & CREB 5 & $4.50^{\mathrm{a}}$ & $0.00^{\mathrm{q}}(0.00)$ \\
\hline $\mathbf{6 .}$ & CREB 6 & $4.50^{\mathrm{a}}$ & $0.00^{\mathrm{q}}(0.00)$ \\
\hline $\mathbf{7 .}$ & CREB 7 & $4.50^{\mathrm{a}}$ & $0.00^{\mathrm{q}}(0.00)$ \\
\hline $\mathbf{8 .}$ & CREB 8 & $2.13^{\mathrm{gh}}$ & $52.59^{\mathrm{jkl}}(46.47)$ \\
\hline $\mathbf{9 .}$ & CREB 9 & $2.17^{\mathrm{g}}$ & $51.85^{\mathrm{jkl}}(46.04)$ \\
\hline
\end{tabular}




\begin{tabular}{|c|c|c|c|}
\hline 10. & CREB 10 & $2.07^{\text {ghi }}$ & $54.07^{\mathrm{ijk}}(47.32)$ \\
\hline 11. & CREB 11 & $1.93^{\mathrm{jk}}$ & $57.04^{\text {efgh }}(49.03)$ \\
\hline 12. & CREB 12 & $2.30^{\text {cdef }}$ & $48.89^{\mathrm{m}}(44.35)$ \\
\hline 13. & CREB 13 & $2.83^{\mathrm{b}}$ & $37.04^{\mathrm{p}}(37.47)$ \\
\hline 14. & CREB 14 & $4.50^{\mathrm{a}}$ & $0.00^{\mathrm{q}}(0.00)$ \\
\hline 15. & CREB 15 & $1.30^{\mathrm{p}}$ & $71.11^{b}(57.47)$ \\
\hline 16. & CREB 16 & $1.80^{\operatorname{lmn}}$ & $60.00^{\mathrm{d}}(50.75)$ \\
\hline 17. & CREB 17 & $1.90^{\mathrm{jkl}}$ & $57.78^{\operatorname{defg}}(49.46)$ \\
\hline 18. & CREB 18 & $2.37^{\mathrm{cd}}$ & $47.41^{\mathrm{mno}}(43.50)$ \\
\hline 19. & CREB 19 & $1.83^{\mathrm{klmn}}$ & $59.26^{\mathrm{de}}(50.32)$ \\
\hline 20. & CREB 20 & $2.40^{c}$ & $46.67^{\mathrm{mno}}(43.07)$ \\
\hline 21. & CREB 21 & $1.30^{\mathrm{p}}$ & $71.11^{\mathrm{b}}(57.47)$ \\
\hline 22. & CREB 22 & $2.30^{\text {cdef }}$ & $48.89^{\mathrm{m}}(44.35)$ \\
\hline 23. & CREB 23 & $2.33^{\text {cde }}$ & $48.15^{\mathrm{mn}}(43.92)$ \\
\hline 24. & CREB 24 & $4.50^{\mathrm{a}}$ & $0.00^{\mathrm{q}}(0.00)$ \\
\hline 25. & CREB 25 & $4.50^{\mathrm{a}}$ & $0.00^{\mathrm{q}}(0.00)$ \\
\hline 26. & CREB 26 & $4.50^{\mathrm{a}}$ & $0.00^{\mathrm{q}}(0.00)$ \\
\hline 27. & CREB 27 & $4.50^{\mathrm{a}}$ & $0.00^{\mathrm{q}}(0.00)$ \\
\hline 28. & CREB 28 & $4.50^{\mathrm{a}}$ & $0.00^{\mathrm{q}}(0.00)$ \\
\hline 29. & CREB 29 & $4.50^{\mathrm{a}}$ & $0.00^{\mathrm{q}}(0.00)$ \\
\hline 30. & CREB 30 & $2.33^{\text {cde }}$ & $48.15^{\mathrm{mn}}(43.92)$ \\
\hline 31. & CREB 31 & $4.50^{\mathrm{a}}$ & $0.00^{\mathrm{q}}(0.00)$ \\
\hline 32. & CREB 32 & $4.50^{\mathrm{a}}$ & $0.00^{\mathrm{q}}(0.00)$ \\
\hline 33. & CREB 33 & $4.50^{\mathrm{a}}$ & $0.00^{\mathrm{q}}(0.00)$ \\
\hline 34. & CREB 34 & $4.50^{\mathrm{a}}$ & $0.00^{\mathrm{q}}(0.00)$ \\
\hline 35. & CREB 35 & $4.50^{\mathrm{a}}$ & $0.00^{\mathrm{q}}(0.00)$ \\
\hline 36. & CREB 36 & $1.60^{\circ}$ & $64.44^{c}(53.38)$ \\
\hline 37. & CREB 37 & $1.17^{\mathrm{q}}$ & $74.07^{\mathrm{a}}(59.37)$ \\
\hline 38. & CREB 38 & $1.97^{\mathrm{ij}}$ & $56.30^{\text {fghi }}(48.60)$ \\
\hline 39. & CREB 39 & $2.07^{\mathrm{ghi}}$ & $54.08^{\mathrm{ij}}(47.32)$ \\
\hline 40. & CREB 40 & $4.50^{\mathrm{a}}$ & $0.00^{\mathrm{q}}(0.00)$ \\
\hline 41. & Control & $4.50^{\mathrm{a}}$ & $0.00^{\mathrm{q}}(0.00)$ \\
\hline \multicolumn{2}{|c|}{ C.D (P=0.05 \%) } & 0.10 & $2.24(1.33)$ \\
\hline \multicolumn{2}{|c|}{$\operatorname{SEm}( \pm)$} & 0.04 & $0.79(0.47)$ \\
\hline \multicolumn{2}{|c|}{ SE (d) } & 0.05 & $1.12(0.67)$ \\
\hline \multicolumn{2}{|r|}{ C.V } & 1.92 & $4.82(3.30)$ \\
\hline
\end{tabular}

Note: Values in the parenthesis are angular transformed values.

The figures with similar alphabet do not differ significantly. 


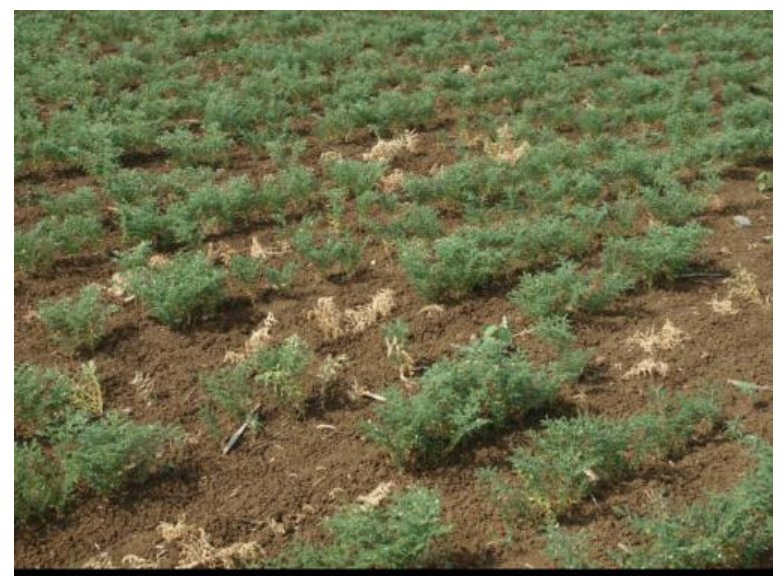

Dry root rot infected field

Plate 1: Dry root rot symptoms on chickpea under field conditions

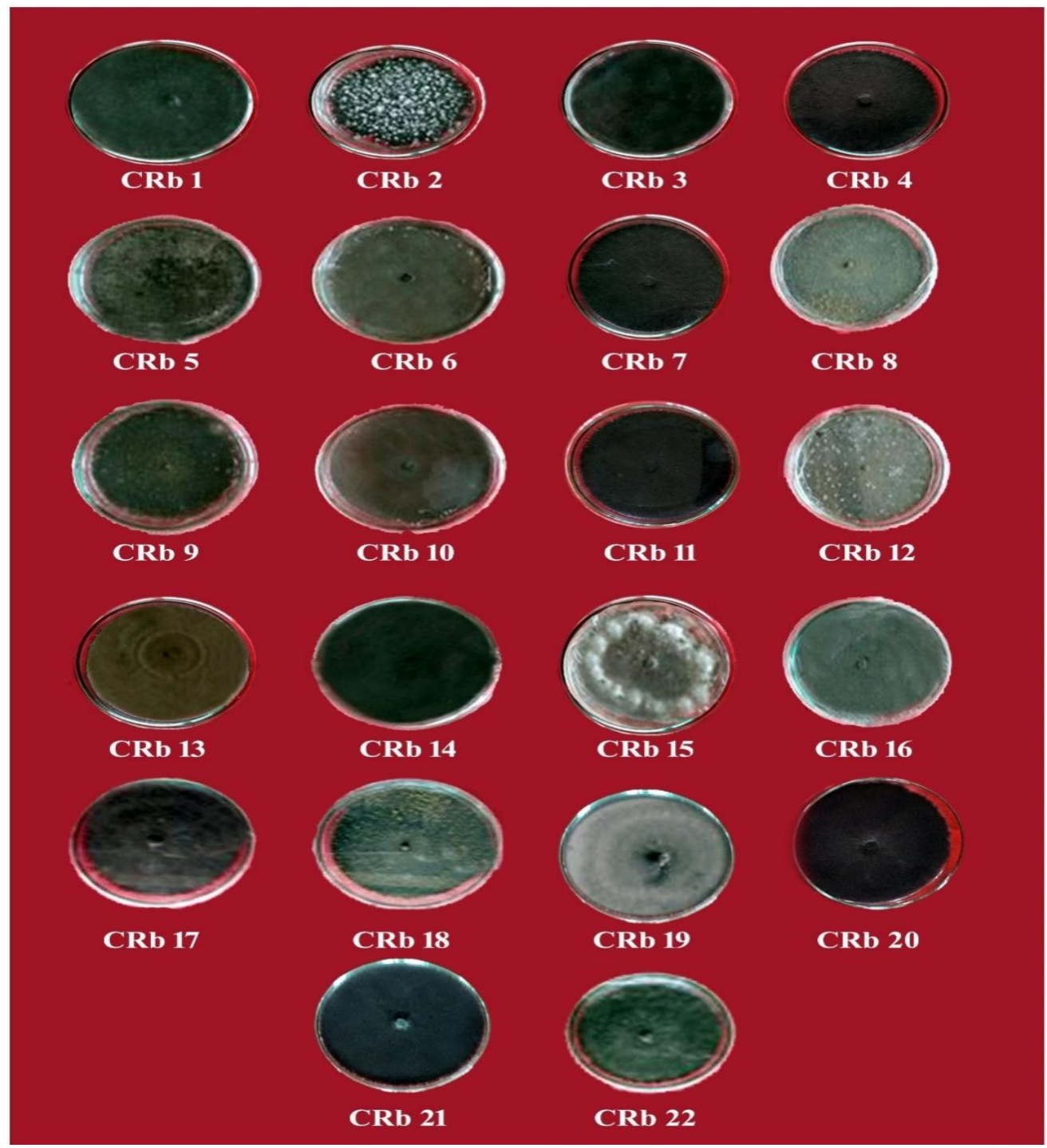

Plate 2: Pure cultures of different $\boldsymbol{R}$. bataticola isolates 


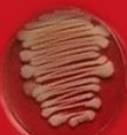

CREB 1
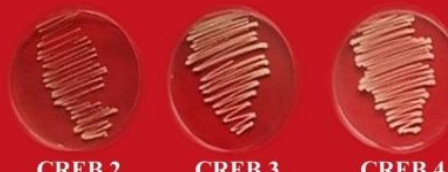

CREB 3

CREB 4
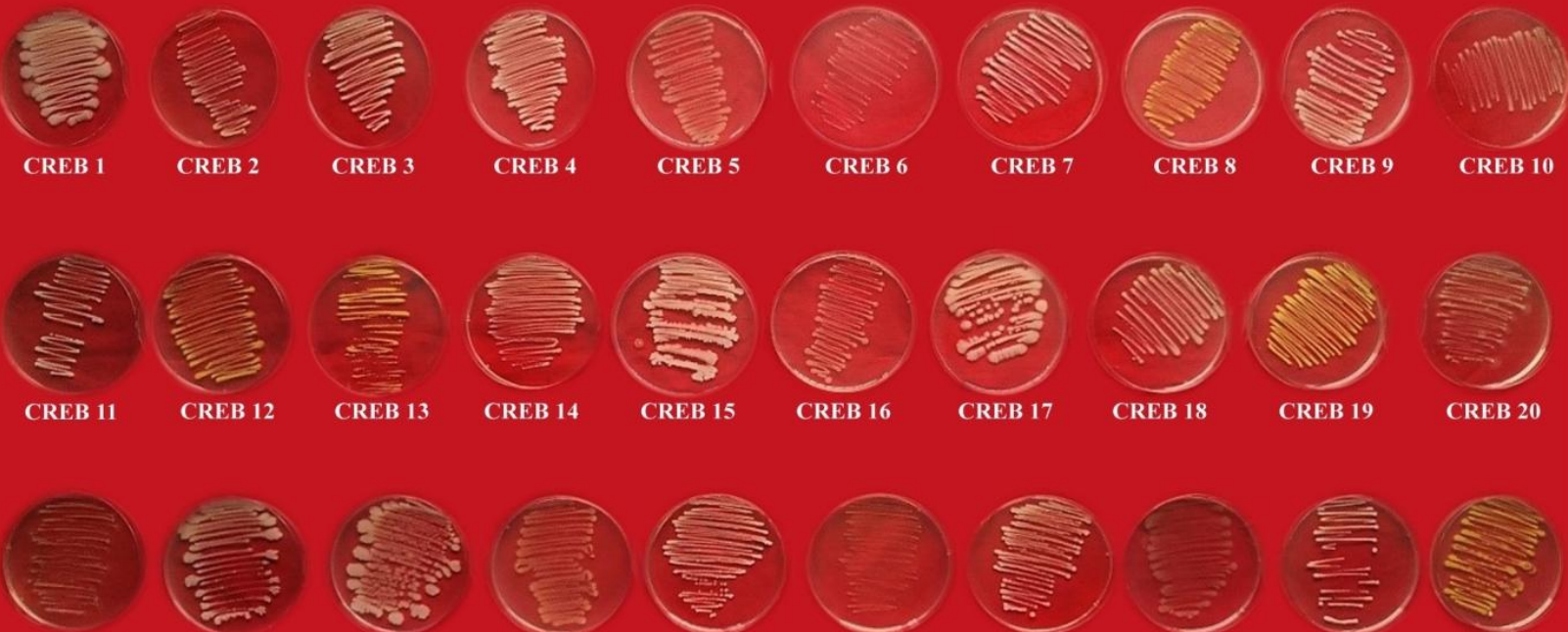

CREB 21

CREB 22
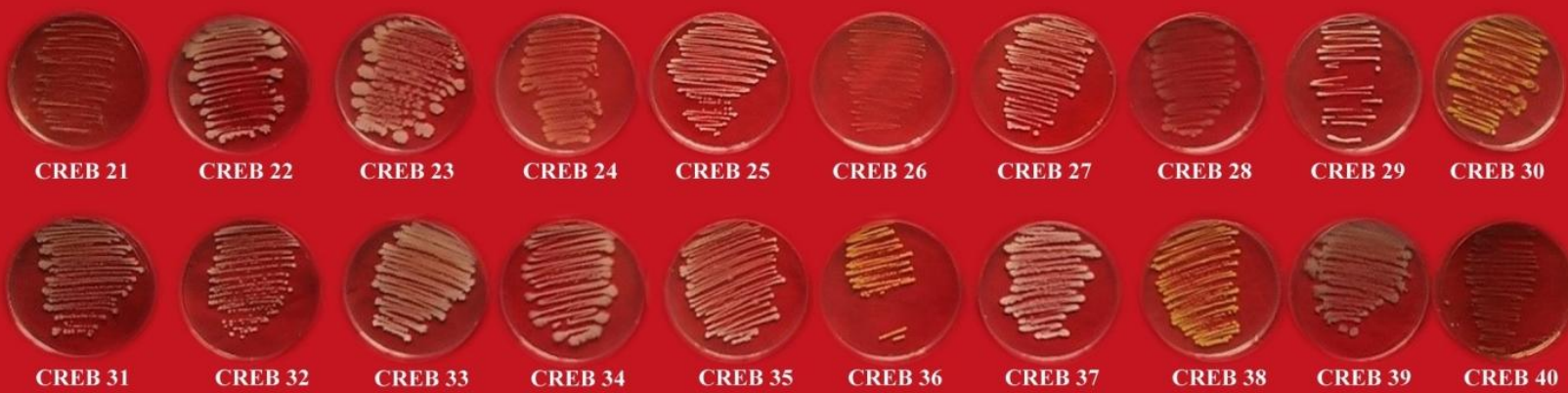

\section{Plate 3: Pure cultures of different root endophytic bacterial isolates}

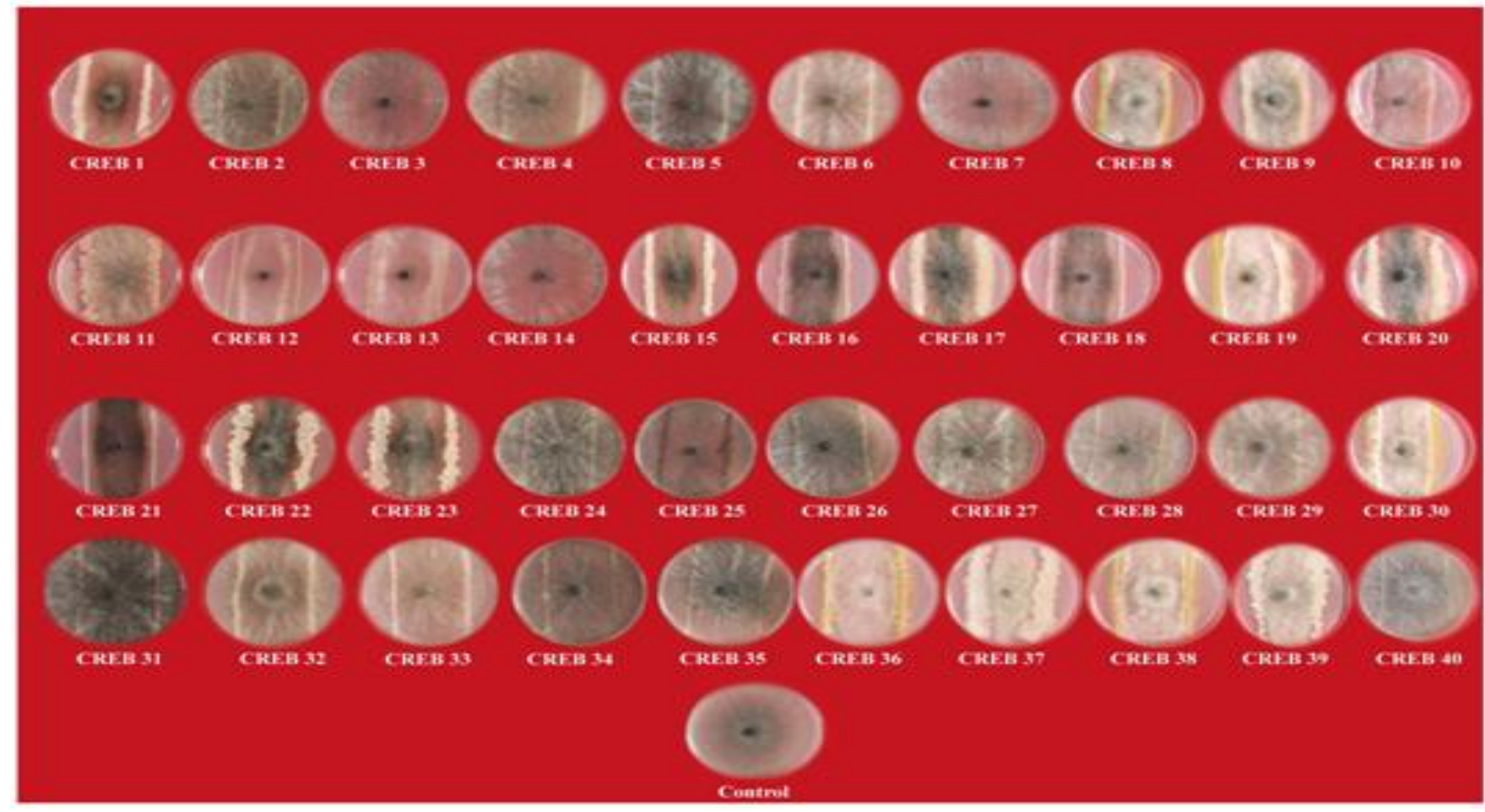

Plate 4: In vitro evaluation of endophytic bacteria against $R$. bataticola by dual culture technique 
A total of 40 endophytic bacterial isolates were evaluated for their antagonistic activity against chickpea dry root rot causing pathogen $R$. bataticola. From the data it is evident that, among the isolates tested CREB 37 showed significantly maximum inhibition (74.07 \%) against $R$. bataticola followed by CREB 15 (71.11\%), CREB 21 (71.11\%), CREB 36 (64.44 \%), CREB $16(60.00 \%)$ and least $(0.00 \%)$ was recorded with control, CREB 2, CREB 3, CREB 4, CREB 5, CREB 6, CREB 7, CREB 14, CREB 24, CREB 25, CREB 26, CREB 27, CREB 28, CREB 29, CREB 31, CREB 32, CREB 33, CREB 34, CREB 35 and CREB 40.

Among the isolates CREB 37 showed maximum antifungal efficiency with $74.04 \%$ inhibition against test pathogen. Based on the results it was considered as a potential isolate and used for further studies.

These results were in concurrence with Veena et al., (2014) who reported that among the 20 root endophytic bacterial isolates tested, the isolate CREB-13 showed the maximum inhibition $(95.55 \%)$ in growth of $R$. bataticola in dual culture. While, Bhavani et $a l$. , (2015) tested sixty three endophytic bacterial isolates for their antagonistic properties against $R$. bataticola causing dry root rot of chickpea by dual culture technique. Out of them, five isolates showed significant inhibition. The isolate B5 was shown the most significant inhibition with $81 \%$, K1 with 77 $\%, \mathrm{~K} 2$ with $75 \%, \mathrm{C} 2$ and A8 with $74 \%$.

Brunda et al., (2018) also tested the antagonistic effect of 30 bacterial endophytes against $S$. rolfsii, $R$. bataticola and $F$. oxysporum through dual culture technique. The bacterial endophytes RB-KK-6 (40.78 $\%)$, SB-BS-6 (50.08\%) and LB-BU-1 (47.02 $\%$ ) were found effective against $S$. rolfsii and the isolates SB-DG-11 (47.41\%), LB-BiN-8 $(41.22 \%)$ were effective against $R$. bataticola. The effective bacterial endophytes against $F$. oxysporum were RB-HS-1 (41.99 $\%)$, SB-BiJ-9 (40.07 \%), LB-BU-1 (54.20\%) and LB-BV-2 (51.64\%). Similarly, Ferchichi et al., (2019) assessed antifungal activity of 22 endophytic bacterial isolates against $M$. phaseolina and Alternaria alternate phytopathogens by dual culture technique. Four strains affiliated to Pseudomonas genus (Pseudomonas brenneri LJ215, Pseudomonas frederiksbergensis LB113, Pseudomonas helleri LJ127 and Pseudomonas rhodesiae LJ22) showed an anti-fungal activity against these two phytopathogens simultaneously. The results are also in accordance with the findings of Gong et al., (2006), Zin et al., (2007), Aravind et al., (2009), Uppala et al., (2009) and Zhao et al., (2018).

Summary and Conclusion are as follows:

Dry root rot of chickpea distributed in all the surveyed districts of Andhra Pradesh. Different isolates of $R$. bataticola were isolated from the samples collected from major chickpea growing areas of Andhra Pradesh. The isolates were purified by single sclerotial isolation technique and were identified based on morphological and cultural characters.

Pathogenicity of the $22 R$. bataticola isolates was proved by soil inoculation method. Based on the results $\mathrm{CRb} 9$ was considered as a most virulent pathogen isolate.

A total of 40 antagonistic endophytic bacteria were isolated from healthy roots of different chickpea varieties which are popularly cultivated in surveyed areas (Kurnool, Y.S.R Kadapa, Prakasam, Anantapuramu and Guntur).

The antagonistic effect of endophytic bacterial isolates was assessed based on their ability to inhibit the pathogen growth in dual 
culture. Among the isolates CREB 37 showed maximum antifungal efficiency against virulent $R$. bataticola isolate CRb 9 and it was considered as a potential isolate.

\section{References}

Aravind, R., Kumar, A., Eapen, S.J and Ramana, K.V. 2009. Endophytic bacterial flora in root and stem tissues of black pepper (Piper nigrum L.) genotype: isolation, identification and evaluation against Phytophthora capsici. Letters in Applied Microbiology. 48: 58-64.

Barnett, H.L and Barry, B.H. 1972. Illustrated Genera of Imperfect Fungi. Burgess publishing company, Minnesota.

Bhavani, D.A., Kumari, M.A and Kumar, A.K. 2015. Chickpea endophytic bacteria inhibiting dry root rot fungus Rhizoctonia bataticola. International Journal of Scientific and Engineering Research. 6(2): 83-85.

Brunda, K.S., Jahagirdar, S and Kambrekar, D. 2018. Antagonistic activity of bacterial endophytes against major soilborne pathogens of soybean. Journal of Entomology and Zoology Studies. 6(6): 43-46.

Chaturvedi, H., Singh, V and Gupta, G. 2016. Potential of bacterial endophytes as plant growth promoting factors. Journal of Plant Pathology and Microbiology. 7: $1-2$.

Commonwealth Mycological Institute (CMI), 1970. Description of pathogenic fungi and bacteria No. 275. Kew, England.

Dastur, J.F. 1935. Gram wilts in the central provinces. Agriculture livestock India. 4: 615- 627.

Devi and Singh, R.H. 1998. Studies on virulence of Macrophomina phaseolina isolates from blackgram and greengram. Journal of Mycology and Plant Pathology. 22(2): 196-198.
Dixit, G.P., Srivastava, A.K and Singh, N.P. 2019. Marching towards self sufficiency in chickpea. Current Science. 116(2): 239-242.

Ferchichi, N., Toukabri, W., Boularess, M., Smaoui, A., Mhamdi, R and Trabelsi, D. 2019. Isolation, identification and plant growth promotion ability of endophytic bacteria associated with lupine root nodule grown in Tunisian soil. Archives of Microbiology. 1-16.

Gong, M., Wanq, J.D., Zhanq, J., Yang, H., Lu, X.F., Pei, Y and Cheng, J. Q. 2006. Study of the antifungal ability of Bacillus subtilis strain PY-1in vitro and identification of its antifungal substance (Iturin A). Acta Biochem Biophys Sinica. 38(4): 233-40.

in chickpea. Current Science. 116(2): 239242.

Jasim, B., Benny, R., Sabu, R., Mathew, J and Radha Krishnam, E. K. 2016. metabolite and mechanistic basis of antifungal property exhibited by endophytic Bacillus amyloliquefaciens BMB 1. Applied Biochemistry and Biotechnology. 7: 1-15.

Kanchan, C and Biswas, S.K. 2009. Morphological and pathogenic variability of Rhizoctonia bataticola (Taub.) Butler, causal agent of leaf spot and blight disease of pigeon pea. Annals of Plant Protection Sciences. 17(1): 124-126.

Katariya, L., Gaur, V.K and Sharma R. 2007. Assessment of genetic variability in Rhizoctonia bataticola infecting chickpea isolates using pathogenicity and RAPD markers. Indian Journal of Mycology and Plant Pathology. 37(3): 491-494.

Lahlali, R., Baji, M and Jijakli, M.H. 2007. Isolation and evaluation of bacteria and fungi as biological control agents against Rhizoctonia solani. Communications in Agricultural and 
Applied Biological Sciences.72(4): 973982.

Lakhran, L., Ahir, R.R., Choudhary, $\mathrm{M}$ and Choudhary, S. 2018. Isolation, purification, identification and pathogenicity of Macrophomina phaseolina (Tassi) Goid caused dry root rot of chickpea. Journal of Pharmacognosy and Phytochemistry. 7(3): 3314-3317.

Manjunatha, $\mathrm{H}$ and Saifulla, M. 2016. Variation in virulence of Macrophomina phaseolina isolates causing dry root rot of chickpea and performance of chickpea genotypes against this disease. Legume Research. $1-5$.

Nene, Y.L., Reddy, M.V., Haware, M.P., Ghanekar, A.M and Amin, K.S. 1991. Field diagnosis of chickpea diseases and their control. ICRISAT Information Bulletin. 28: 52.

Nene, Y.L., Reddy, M.V., Haware, M.P., Ghanekar, A.M., Amin, K.S., Pande, S and Sharma, M. 2012. Field diagnosis of chickpea diseases and their control. Information Bulletin. 28: 1-58.

Rangaswamy, G and Mahadevan, A. 1999. Diseases of Crop Plants in India. (4th edition) Prentice Hall of India Pvt. Ltd, New Delhi. 607.

Reddy, P.B., Rani, J., Reddy, M.S and Vijay Krishna Kumar. K. 2010. Isolation of siderophore- producing strains of rhizobacterial fluorescent pseudomonads and their biocontrol against rice fungal pathogens. International Journal of Applied Biology and Pharmaceutical Technology.1: 133-137.

Saini, R., Dudeja, S.S., Giri, R and Kumar, V. 2013. Isolation, characterization, and evaluation of bacterial root and nodule endophytes from chickpea cultivated in Northern India. Journal of Basic Microbiology. 53: 1-8.
Santoyo, G., Hagelsie, M.G., Carmen, M and Bernard, R.M.O. 2016. Plant growthpromoting bacterial endophytes. Microbiological Research. 183: 92-99.

Sharma, M and Pande, S. 2013. Unravelling effects of temperature and soil moisture stress response on development of dry root rot [Rhizoctonia bataticola (Taub.)] Butler in chickpea. American Journal of Plant Science. 4: 584-589.

Sharma, M., Ghosh, R and Pande, S. 2015. Dry root rot (Rhizoctonia bataticola (Taub.) Butler): an emerging disease of chickpea-where do we stand?. Archives of Phytopathology and Plant Protection. 48(13): 797-812.

Uppala, S.S., Beena, S., Chapala, M.M and Bowen, K.L. 2009. Bioefficacy of endophytes in the management of leaf blight disease of amaranth. Proceedings of First Asian PGPR Congress for Sustainable Agriculture. 21-24.

Veena, G.A and Reddy, N.P.E. 2016. Integrated disease management of dry root rot of chickpea. International Journal of Applied Biology and Pharmaceutical Technology. 7(2): 4554.

Veena, G.A., Reddy, N.P.E., Reddy, B.V.B and Prasanthi, L. 2014. Pathogenicity tests and evaluation of efficacy of fungicides against Rhizoctonia bataticola, the causal agent of dry root rot of chickpea. International Journal of Applied Biology and Pharmaceutical Technology. 5(1): 283-287.

Veena, G.A., Reddy, N.P.E., Reddy, B.V.B and Prasanthi, L. 2014. Pathogenicity tests and evaluation of efficacy of fungicides against Rhizoctonia bataticola, the causal agent of dry root rot of chickpea. International Journal of Applied Biology and Pharmaceutical Technology. 5(1): 283-287.

Vishwadar and Sarbhoy, A.K. 1993. An a typical isolate of Rhizoctonia 
bataticola. Indian Phytopathology. 245246.

Zhao, L., Xu, Y and Lai, X. 2018. Antagonistic endophytic bacteria associated with nodules of soybean (Glycine $\max$ L.) and plant growthpromoting properties. Brazilian Journal of Microbiology. 49: 269-278.
Zin, N.M., Nurul, I.M., Sarmin., Ghadin, N., Dayang, F., Basri., Sidik, N.M., Hess, W.M and Strobel, G.A. 2007. Bioactive endophytic streptomycetes from the Malay Peninsula. Federation of European Microbiological Societies Microbiology Letters. 274: 83-88.

\section{How to cite this article:}

Chiranjeevi, N., M. Reddi Kumar, B. Padmodaya, N.C. Venkateswarlu, P. Sudhakar, R. Sarada Jayalakshmi Devi and Jyothsna, M.K. 2020. In vitro Evaluation of Endophytic Bacteria for their Efficacy against Chickpea Dry Root Rot Causing Pathogen (Rhizoctonia bataticola (Taub.) Butler). Int.J.Curr.Microbiol.App.Sci. 9(12): 2028-2043. doi: https://doi.org/10.20546/ijcmas.2020.912.240 